Artikel Penelitian

\title{
Efektivitas antibakteri senyawa katekin dari ekstrak daun teh (Camelia sinensis L. var assamica) terhadap bakteri Pseudomonas fluorescens
}

\author{
Elly Rustanti
}

Sekolah Tinggi Ilmu Kesehatan Husada, Jombang, Indonesia

\section{INFO ARTIKEL}

Sejarah arikel:

Submisi

Revisi

Diterima

Tersedia online: 4 Oktober 2016

Penulis korespondensi:

Email: eilrose1211.er@gmail.com

\section{ABSTRAK}

Tea leaves is one of natural product that used as antibacterial. Antibacterial compound can be used as natural preservative. The aim was to determine effectiveness of tea leaves as natural antibacterial to inhibit Pseudomans fluorescens. Tea leaves was extracted by maceration. Separation the extract (catechin) conducted by analytical TLC (chromatography thin layer) using various eluent such as ethyl acetate : aquadest : formic acid (18:1:1), toluene : acetone : formic acid (3:3:1) and chloroform : methanol : aquadest (6:5:3.5:1). Analytical TLC analysis showed the best eluent, ethyl acetate : aquadest : formic acid. The best eluent was used for preparation using preparative TLC. Antibacterial test showed that isolate no.2 was given the highest effectiveness to bacterium $P$. fluorescens with inhibition zone $23.3 \mathrm{~mm}$.

Keywords: tea leaves, catechin, antibacteri, Pseudomans fluorescens

Daun teh adalah salah satu bahan alam yang dapat digunakan sebagai antibakteri. Zat tersebut dapat juga digunakan sebagai pengawet alami. Penelitian ini bertujuan untuk mengetahui keefektifan daun teh sebagai antibakteri alami dalam menghambat bakteri Pseudomonas fluorescens. Proses ekstraksi dauh teh yang dilakukan dengan metode maserasi. Pemisahan ekstrak daun teh (katekin) dilakukan dengan Kromatografi Lapis Tipis (KLT) analitik dengan variasi eluen yaitu etil asetat:air:asam format (18:1:1), toluena:aseton:asam format (3:3:1) dan kloroform:metanol:air $(6,5: 3,5: 1)$. Hasil KLT analitik menunjukkan bahwa eluen terbaik adalah etil asetat:air:asam format. Eluen tersebut digunakan untuk pemisahan menggunakan KLT preparatif. Hasil uji antibakteri menunjukkan bahwa isolat 2 dari ekstrak daun teh memberikan efektivitas terbaik sebagai antibakteri $P$. Fluorescens dengan zona hambat $23,3 \mathrm{~mm}$.

Kata Kunci: daun teh, katekin, antibakteri, Pseudomonas fluorescens

\section{Pendahuluan}

Bahan pangan merupakan jenis bahan yang mudah mengalami kerusakan atau penurunan mutu. Salah satu cara pencegahannya adalah dengan penambahan bahan pengawet. Bahan ini dapat mencegah kerusakan biologi yang disebabkan oleh mikroorganisme. Oleh karena itu, bahan pengawet dapat berfungsi sebagai antibakteri. Pengunaan bahan pengawet atau senyawa antibakteri telah digunakan sejak lama (Ardiansyah, 2007). Saat ini, banyak industri 
pangan yang menggunakan pengawet sintesis dalam setiap produksinya. Fakta tersebut cukup meresahkan masyarakat karena dapat mengganggu kesehatan.

Pseudomonas fluorescens adalah salah satu bakteri yang dapat penyebab berbagai jenis kerusakan bahan pangan. Bakteri dengan spesies ini dapat memproduksi enzim yang dapat memecah baik komponen lemak maupun protein dari bahan pangan (Buckle dkk., 2007). Bakteri golongan Pseudomonas dapat memecah rangkaian karbohidrat dengan enzim-enzim oksidase yang dihasilkan sehingga menimbulkan pewarnaan pada ikan. $P$. flourescens dapat menimbulkan noda-noda berwarna kuning atau kuning kehijauan sebelum ikan menjadi busuk (Hadiwiyoto, 1993).

Indonesia merupakan salah satu negara dengan perkebunan teh yang cukup luas. Tanaman teh yang tumbuh di Indonesia mayoritas merupakan varietas Assamica. Teh varietas ini memiliki kandungan katekin (zat bioaktif utama dalam teh) yang tinggi. Katekin termasuk senyawa golongan polifenol. Oleh karena itu, teh varietas ini berpotensi untuk dikembangkan menjadi produk olahan pangan. Selain itu, teh juga bisa digunakan sebagai bahan aditif berupa zat pengawet pada ikan, produk kosmetik dan makanan (Hartoyo, 2003).

Penelitian tentang efisiensi polifenol daun teh melawan pemudaran warna oleh sinar UV pada ikan salmon telah dilakukan. Salmon merupakan ikan dengan kulit berwarna merah karena adanya kandungan karoteinoid. Karotenoid tersebut akan memudar warnanya seiring dengan matinya ikan. Namun, dengan penambahan polifenol teh, pemudaran warna merah daging ikan dapat dicegah lebih lama (Syah, 2006).

Berdasarkan uraian di atas, perlu dilakukan penelitian tentang uji aktivitas antibakteri senyawa katekin dari daun teh (Camellia sinensis, L. var. Assamica) yang efektif sebagai antibakteri alami dalam bentuk ekstrak antibakteri. Penelitian ini merupakan salah satu upaya untuk mengoptimalkan pemanfaatan bahan alam hayati Indonesia. Pencarian eluen terbaik juga perlu dalam pemisahan senyawa aktif khususnya senyawa katekin sehingga diketahui fraksi aktif yang mempunyai potensi sebagai antibakteri.

\section{Bahan dan metode}

\subsection{Bahan}

Pucuk daun teh segar diambil dari perkebunan teh Wonosari, Lawang, Malang. Bahan kimia yang digunakan antara lain kloroform, metanol, etil asetat, asam format, aseton, dan toluena. Bahan untuk uji antibakteri antara lain etanol $90 \%$, kertas cakram, nutrien agar (NA), nutrien borth (NB), streptomicin, biakan murni $P$. fluorescens. Bahan kimia yang lain adalah plat silika gel $\mathrm{GF}_{254}$, akuades, amoniak dan larutan $\mathrm{FeCl}_{3}$.

\subsection{Preparasi sampel}

Daun teh sebanyak $350 \mathrm{~g}$ dicuci, dipotong kecil-kecil dan dikeringkan dalam oven pada suhu 30-37 $\mathrm{C}$ sampai diperoleh berat konstan. Kemudian dihaluskan menjadi serbuk, hasil yang diperoleh berupa serbuk daun teh.

\subsection{Ekstraksi senyawa katekin}

Ekstraksi senyawa dilakukan dengan metode maserasi. Lima puluh gram serbuk daun teh direndam dalam $200 \mathrm{~mL}$ aquades selama 2,5 jam sambil sesekali dikocok (Hukmah, 2007). Ekstrak daun teh dipartisi dengan $100 \mathrm{~mL}$ kloroform dan diulang sebanyak 3 kali. Fase air yang diperoleh dimasukkan dalam corong pisah dan ditambahkan $100 \mathrm{~mL}$ etil asetat. Proses tersebut diulang 3 kali. Fase etil asetat yang diperoleh dipekatkan dengan rotary evaporator. Ekstrak pekat yang diperoleh digunakan untuk uji selanjutnya.

\subsection{Pemisahan ekstrak dengan KLTA}

Pemisahan dengan KLTA menggunakan plat silika gel $\mathrm{GF}_{254} 2 \times 10 \mathrm{~cm}^{2}$ yang sudah diaktifkan dengan pemanasan pada suhu $30-40^{\circ} \mathrm{C}$ selama 10 menit. Ekstrak pekat ditotolkan pada jarak $1 \mathrm{~cm}$ dari tepi bawah plat dan dielusi dengan berbagai eluen. Eluen yang digunakan adalah etil asetat : air : asam format (18:1:1), toluena : aseton : asam format (3:3:1), dan kloroform : methanol : air (6,5:3,5:1) (Amarowicz dkk., 2005). Noda-noda pada permukaan plat diuapi dengan amoniak dan diperiksa di bawah sinar UV pada panjang gelombang $254 \mathrm{~nm}$. Warna biru pucat yang terbentuk menunjukkan adanya katekin. Noda berwarna hitam kebiruan setelah disemprot $\mathrm{FeCl}_{3}$ menunjukkan adanya katekin (Robinson, 1995) 


\subsection{Pemisahan ekstrak dengan KLTP}

Pemisahan dengan KLTP plat silika gel $\mathrm{GF}_{254}$ berukuran $5 \times 20 \mathrm{~cm}^{2}$. Ekstrak pekat hasil ekstraksi ditotolkan di sepanjang plat dan dielusi dengan menggunakan eluen terbaik pada KLTA. Nodanoda pada permukaan plat diuapi dengan uap amoniak. Adanya katekin ditunjukkan dengan warna biru pucat di bawar sinar UV pada panjang gelombang $245 \mathrm{~nm}$. Noda yang telah disemprot larutan $\mathrm{FeCl}_{3}$ akan membentuk warna hitam kebiruan apabila mengandung katekin (Robinson, 1995). Noda yang diperoleh dikerok dan dilarutkan dalam air untuk uji antibakteri. Selain itu, noda dilarutkan dalam metanol untuk identifikasi dengan spektrofotometer FTIR.

\subsection{Uji antibakteri}

\subsubsection{Peremajaan bakteri $P$. fluorocens}

Biakan murni $P$. fluorescens diremajakan pada media padat. Proses peremajaan bakteri dilakukan secara aseptik. Selanjutnya biakan bakteri $P$. fluorescens diinkubasi pada suhu $25^{\circ} \mathrm{C}$.

\subsubsection{Pembuatan kurva pertumbuhan bakteri $P$. fluorescens}

Satu tabung kultur bakteri ditumbuhkan dalam $100 \mathrm{~mL}$ NB dan diinkubasi pada suhu $25^{\circ} \mathrm{C}$. Setiap selang waktu 2 jam, kultur diambil $1 \mathrm{~mL}$ dan diencerkan sampai volume $10 \mathrm{~mL}$ sampai tumbuh optimum. Setelah itu, dilakukan pengukuran densitas optik pertumbuhan sel pada panjang gelombang $620 \mathrm{~nm}$ menggunakan spektronik. Kurva pertumbuhan bakteri dibuat dengan menghubungkan waktu inkubasi dengan densitas optik.

\subsubsection{Pembuatan larutan bakteri P. fluorocens}

Satu ose dari hasil peremajaan biakan murni $P$. fluorescens dilarutkan dalam $10 \mathrm{~mL}$ akuades steril.

\subsubsection{Uji efektivitas antibakteri}

Larutan nutrien agar dituang dalam cawan petri dan ditambahkan dengan $0,1 \mathrm{~mL}$ larutan bakteri $P$. fluorescens, kemudian dihomogenkan dan dibiarkan memadat. Kertas cakram yang telah dipreparasi diletakkan di atas permukaan media bakteri dan diinkubasi pada suhu $25^{\circ} \mathrm{C}$ selama masa pertumbuhan optimum bakteri. Selanjutnya, diukur diameter zona hambatnya. Diameter zona hambat adalah diameter yang tidak ditumbuhi bakteri di sekitar kertas cakram dikurangi diameter kertas cakram

Preparasi kertas cakram yaitu merendam kertas cakram dalam isolat-isolat hasil KLTP dengan variasi sampel. Kontrol positif dibuat dengan merendam kertas cakram dalam streptomisin $6,25 \mathrm{mg} / \mathrm{mL}$, sedangkan kontrol negatif dibuat dengan merendam kertas cakram dalam akuades steril.

\section{Hasil dan pembahasan}

\subsection{Preparasi sampel}

Pengeringan dilakukan agar sampel mudah untuk dihaluskan hingga menjadi serbuk daun teh dan memudahkan dalam pengekstraksian. Proses memberikan nilai rendemen sebesar 17,24\%. Sampel yang digunakan berupa serbuk daun teh.

\subsection{Ekstraksi senyawa katekin}

Proses ekstraksi merupakan penarikan komponen aktif menggunakan pelarut tertentu (Harbone, 1987). Komponen aktif daun teh adalah senyawa katekin menggunakan metode maserasi. Pemilihan metode maserasi pada penelitian ini dikarenakan senyawa katekin rentan terhadap panas. Proses ekstraksi akan berlangsung optimal dengan tersedianya waktu kontak yang cukup antara pelarut dan sampel. Selama proses perendaman dilakukan beberapa kali pengocokan untuk menyempurnakan kontak antara pelarut dan sampel. Ekstrak daun teh yang diperoleh berwarna hijau.

Ekstrak daun teh dipartisi dengan kloroform untuk mengambil senyawa-senyawa yang bersifat nonpolar, seperti lemak, klorofil, dan kafein. Penambahan kloroform diulang untuk memaksimalkan proses pengambilan senyawa yang bersifat non polar. Penambahan kloroform menyebabkan terbentuknya dua fase yaitu fase air dan fase kloroform. Fase kloroform dibuang dan fase air diambil untuk dilakukan tahap partisi ke dua.

Fase air dipartisi dengan etil asetat. Penambahan etil asetat berfungsi untuk mengambil senyawa katekin. Penambahan etil asetat diulang untuk memaksimalkan pengambilan senyawa katekin. Pada tahap ini terbentuk dua fase yaitu fase air dan etil asetat. Fase air dibuang dan fase etil asetat diambil. Fase etil asetat berwarna kuning dengan berat 3,52 g. Fase ini dipekatkan dengan rotary evaporator sehingga diperoleh ekstrak pekat. 
Proses evaporasi ini dilakukan untuk menghilangkan sisa etil asetat.

\subsection{Pemisahan ekstrak katekin dengan KLTA}

$\mathrm{KLT}$ merupakan metode pemisahan senyawa kimia dengan menggunakan fase diam dan fase gerak. Pemisahan katekin dari ekstrak daun teh dilakukan menggunakan 3 jenis eluen. Penggunaan berbagai jenis eluen pada pemisahan ini bertujuan untuk mencari eluen terbaik yang dapat memisahkan senyawa katekin yang terkandung dalam daun teh. Hasil elusi ekstrak ini dengan variasi bentuk sampel dapat ditunjukkan pada Tabel 1.

\section{Tabel 1.}

Nilai retention factor (Rf) ekstrak daun teh dengan variasi eluen

\begin{tabular}{cccc}
\hline \multirow{2}{*}{ Noda } & \multicolumn{3}{c}{ Eluen } \\
\cline { 2 - 4 } & A & B & C \\
\hline 1 & 0,19 & 0,44 & 0,87 \\
2 & 0,37 & 0,56 & \\
3 & 0,58 & 0,60 & \\
4 & 0,66 & & \\
5 & 0,79 & & \\
6 & 0,92 & & \\
\hline
\end{tabular}

Eluen $A=$ etil asetat:air: asam format (18:1:1), eluen $B=$ toluena: aseton:asam format (3:3:1), eluen $C=$ kloroform:metanol:air (6,5:3,5:1)

Berdasarkan Tabel 1, eluen terbaik untuk memisahkan ekstrak katekin adalah etil asetat:air:asam format (18:1:1). Eluen ini mampu memisahkan ekstrak dengan menghasilkan noda terbanyak yaitu 6 noda. Banyaknya noda yang terbentuk bergantung pada interaksi antara molekul-molekul senyawa dengan pelarut dan interaksi antara senyawa dengan fase diam. Eluen etil asetat:air:asam format (18:1:1) bersifat agak polar dan kepolarannya hampir sama dengan ekstrak katekin yang dipisahkan sehingga noda yang diperoleh lebih banyak. Menurut Robinson (1995), etil asetat merupakan pelarut yang baik untuk memisahkan katekin.

Jenis fase diam juga dapat mempengaruhi proses pemisahan katekin. Fase diam yang digunakan adalah silika gel. Silika gel adalah bentuk dari silikon dioksida (silika). Pada permukaan silika gel terdapat ikatan Si-O-H selain Si-O-Si. Permukaan silika gel sangat polar dan karenanya gugus $-\mathrm{OH}$ dapat membentuk ikatan hidrogen dengan senyawa-senyawa yang sesuai disekitarnya (Sastrohamidjojo, 2005).

Adanya senyawa katekin pada sampel noda diidentifikasi dengan pereaksi $\mathrm{FeCl}_{3}$. Pereaksi ini banyak digunakan untuk mengidentifikasi senyawa fenol terutama katekin dan akan menghasilkan warna hitam kebiruan (Robinson, 2005). Hasil identifikasi tersebut menunjukkan adanya katekin pada sampel noda. Identifikasi plat diperkuat dengan penyinaran di bawah lampu UV pada panjang gelombang $254 \mathrm{~nm}$. Warna biru pucat yang terbentuk menunjukkan adanya katekin pada noda.

\subsection{Pemisahan ekstrak katekin dengan KLTP}

Pemisahan KLTP menggunakan eluen etil asetat:air:asam format (18:1:1). Eluen ini adalah eluen terbaik hasil KLTA karena mampu memisahkan ekstrak daun teh dengan baik. Noda hasil elusi diidentifikasi menggunakan uap amoniak dan $\mathrm{FeCl}_{3}$. Pemisahan ekstrak katekin dapat dilihat pada Tabel 2.

Tabel 2.

Nilai Rf dan warna noda pada kromatogram hasil KLTP ekstrak daun teh

\begin{tabular}{ccccc}
\hline \multirow{2}{*}{ Noda } & \multirow{2}{*}{$\mathbf{c}$} & \multicolumn{3}{c}{ Warna Noda } \\
\cline { 3 - 5 } & & Tanpa UV & Amoniak & $\mathrm{FeCl}_{3}$ \\
\hline 1 & 0,19 & Kuning & Biru pucat & Hitam biru \\
2 & 0,37 & Kuning & Biru pucat & Hitam biru \\
3 & 0,58 & Ungu & Biru pucat & Hitam biru \\
4 & 0,66 & Kuning & Biru pucat & Hitam biru \\
5 & 0,79 & Ungu & Biru pucat & Hitam biru \\
6 & 0,92 & Orange & Biru pucat & Hitam biru \\
\hline
\end{tabular}

Ke-enam noda akan membentuk warna biru pucat ketika diuapi dan disinari lampu UV. Berdasarkan perubahan warna, noda-noda tersebut diduga merupakan senyawa katekin. Menurut Robinson, (1995), noda pada plat akan berubah menjadi warna biru pucat selelah diuapi dengan amoniak dan diperiksa dibawah sinar ultraviolet (UV). Selain itu, adanya senyawa katekin juga ditunjukkan terbentuknya warna hitam kebiruan setelah disemprot dengan larutan $\mathrm{FeCl}_{3}$. Suatu senyawa yang direaksikan dengan $\mathrm{FeCl}_{3}$ jika terjadi warna hitam kebiruan, merupakan bukti adanya 3,4,5-trihidroksi fenol (seperti galokatekin). Noda yang dihasilkan pada KLT preparatif kemudian dikerok dan dilarutkan dalam air untuk uji antibakteri. 


\subsection{Uji antibakteri}

\subsubsection{Peremajaan bakteri $P$. fluorescens}

Peremajaan bakteri dilakukan untuk menjaga ketersediaan nutrisi, regenerasi bakteri dan menghindari terjadinya perubahan karakter dari biakan murni bakteri. Media pertumbuhan mengandung nutrisi dan zat-zat yang diperlukan oleh bakteri untuk tumbuh. Media cair digunakan untuk produksi dan pembuatan kurva pertumbuhan, sedangkan media padat digunakan untuk peremajaan biakan murni bakteri.

\subsubsection{Pembuatan kurva pertumbuhan $P$. fluorescens}

Kurva pertumbuhan menggambarkan fase-fase yang ada dalam siklus hidup $P$. fluorescens yang meliputi fase adaptasi, fase logaritmik, fase stasioner, dan fase kematian. Kurva pertumbuhan dapat digunakan untuk menentukan waktu panen yang ideal yaitu pada fase stasioner. Pada saat ini, jumlah sel bakteri mendekati maksimum seiring dengan kematian bakteri.

Pembuatan kurva pertumbuhan diawali dengan penumbuhan biakan murni bakteri yang telah diremajakan pada medium cair dan diinkubasi pada inkubator dengan suhu $25^{\circ} \mathrm{C}$. Pada tahap inil dilakukan pengaturan aerasi dan agitasi untuk menjaga kondisi fisika dan kimia media pertumbuhan serta memperlancar transfer nutrisi ke dalam sel.

Pertumbuhan bakteri diamati dengan mengukur densitas optik (DO) media pada panjang gelombang $620 \mathrm{~nm}$ setiap selang waktu 2 jam. Tahap ini dilakukan hingga diperoleh nilai DO media konstan dan akhirnya mengalami penurunan. Nilai DO sebanding dengan massa sel yang terdapat dalam media, makin banyak massa sel makin besar DO. Kurva pertumbuhan dibuat dengan menghubungkan waktu inkubasi dengan nilai DO.

Berdasarkan Gambar 1. diketahui bahwa pertumbuhan $P$. fluorescens melewati 4 fase. Fase pertama adalah adaptasi yang terjadi pada waktu inkubasi 0-6 jam. Pada fase ini, pertumbuhan $P$. fluorescens sangat lamban karena masih beradaptasi dengan media. Fase kedua adalah logaritmik pada waktu inkubasi 6-36 jam. Pada fase ini, $P$. fluorescens mengalami pembelahan sel secara terus menerus yang ditandai meningkatnya jumlah sel sampai mencapai jumlah maksimum. Fase stasioner merupakan fase ketiga yang dicapai waktu inkubasi 36 jam. Fase stationer ditandai dengan pembelahan sel $P$. fluorescens yang sebanding dengan jumlah kematian sehingga tidak terjadi peningkatan jumlah sel. Fase terakhir adalah fase kematian yang terjadi setelah diinkubasi selama 48 jam. Fase ini ditandai dengan penurunan jumlah sel $P$. fluorescens karena kematian sel akibat habisnya nutrisi penting dalam media.

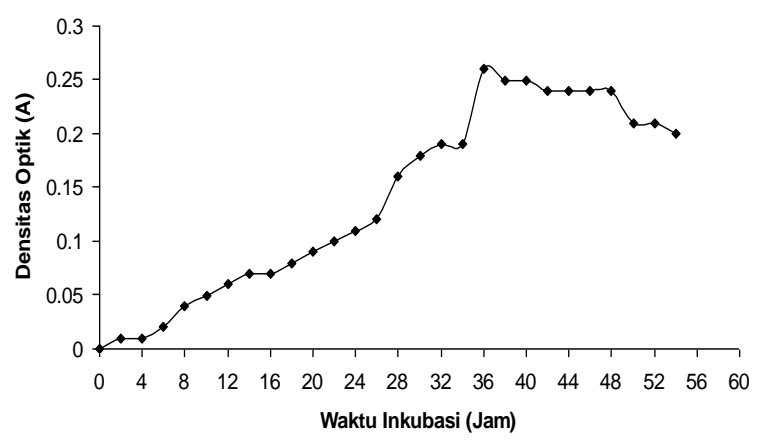

Gambar 1. Kurva pertumbuhan $P$. fluorescens. Kurva ini menunjukkan 4 fase yaitu fase adapatasi pada 0-6 jam, logaritmik 6-36 jam, stationer pada 36 jam, dan kematian pada 48 jam.

Berdasarkan data pada kurva pertumbuhan dapat ditentukan lama waktu inkubasi inokulum dan waktu pengukuran zona hambat. Inkubasi inokulum dilakukan selama 16 jam. Lama waktu tersebut merupakan tengah-tengah fase logaritmik. Penentuan zona hambat bakteri $P$. fluorescens dapat diukur setelah diinkubasi selama 36 jam.

\subsubsection{Efektivitas antibakteri P. fluorescens}

Uji efektivitas senyawa katekin ekstrak daun teh dilakukan dengan mengukur zona hambatan yang terbentuk di sekitar cakram. Kontrol positif digunakan adalah streptomicin $6,25 \mathrm{mg} / \mathrm{mL}$ dan kontrol negatif yang digunakan adalah akuades. Hasil uji efektivitas 6 isolat hasil KLTP dengan konsentrasi $15 \mathrm{mg} / \mathrm{mL}$ dan 3 kali ulangan terhadap bakteri $P$. fluorescens ditunjukkan pada Tabel 3 .

Tabel 3. menunjukkan adanya perbedaan zona hambat bakteri $P$. fluorescens terhadap beberapa isolat. Pada isolat 1 , efektivitas antibakteri mulai tampak dengan zona hambat yang terbentuk sebesar 21,0 mm yang menunjukkan respon hambatan pertumbuhannya kuat, dan pada isolat 2 efektivitas antibakteri juga menunjukkan respon hambatan pertumbuhan yang sangat kuat dengan zona hambat sebesar 23,3 mm. Pada isolat 3, 4, 5, dan 6 kurang memberikan efektivitas antibakteri. Hal tersebut ditunjukkan rendahnya respon 
hambatan pertumbuhan bakteri. Berdasar data Tabel 3 diketahui bahwa isolat yang efektif sebagai antibakteri $P$. fluorescens adalah isolat 2 (Gambar 2).

\section{Tabel 3.}

Data zona hambat senyawa katekin ekstrak daun teh sebagai antibakteri $P$. fluorescens

\begin{tabular}{cccccc}
\hline \multirow{2}{*}{ No. } & \multirow{2}{*}{ Cakram } & \multicolumn{4}{c}{ Diameter zona hambat (mm) } \\
\cline { 3 - 6 } & & $\mathbf{1}$ & $\mathbf{2}$ & $\mathbf{3}$ & Rerata \\
\hline 1. & Isolat 1 & 22,0 & 21,0 & 20,0 & 21,0 \\
2. & Isolat 2 & 23,0 & 23,0 & 24,0 & 23,3 \\
3. & Isolat 3 & 2,00 & 1,00 & 1,00 & 1,30 \\
4. & Isolat 4 & 3,00 & 2,00 & 2,00 & 2,33 \\
5. & Isolat 5 & 2,00 & 2,00 & 1,00 & 1,70 \\
6. & Isolat 6 & 5,00 & 5,00 & 5,00 & 5,00 \\
7. & Kontrol + & 43,0 & 38,0 & 35,0 & 38,7 \\
8. & Kontrol - & 0,00 & 0,00 & 0,00 & 0,00 \\
\hline
\end{tabular}

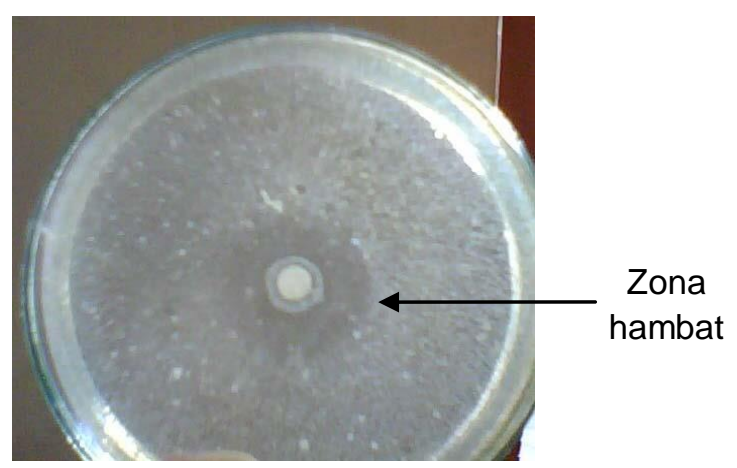

Gambar 2. Zona hambat pada Isolat 2 sebesar 23,3 mm. Isolat 2 menunjukkan respon hambatan terbesar.

\subsection{Identifikasi katekin dengan spekrofotometer FTIR}

Isolat yang terbaik sebagai antibakteri terhadap bakteri $P$. fluorescens adalah isolat 2 dengan nilai Rf 0,37 . Isolat 2 kemungkinan mengandung senyawa EpiCatechin (EC) karena jumlah gugus $\mathrm{OH}$ dan nilai Rf-nya lebih kecil dari EGCG sehingga kurang polar. Berdasarkan penelitian (Cheong ddk., 2005) menyatakan bahwa kadar epicatechin (EC) dalam ekstrak serbuk daun teh lebih besar daripada ekstrak daun teh. Analisa hasil KLT tersebut kemudian didukung dengan identifikasi menggunakan spektrofotometer FTIR.

Berdasarkan hasil pengamatan spektra FTIR dapat diketahui bahwa gugus fungsi yang terdapat pada isolat 2 dari ekstrak daun teh adalah gugus $\mathrm{O}-\mathrm{H}$ dari ikatan hidrogen intermolekuler, $\mathrm{C}-\mathrm{H}$ dari aromatik $\mathrm{CH}_{3}, \mathrm{CH}$ simetris dari $\mathrm{CH}_{2}, \mathrm{CH}_{2}, \mathrm{C}=\mathrm{C}$ alkena, dan C-O dari alcohol (Socrates, 1980). Hasil spektra IR tidak memperlihatkan serapan gugus karbonil di daerah 1650-1700 cm-1 (Corpriady dkk., 2001). Data speltrum IR menunjukkan adanya serapan gugus hidroksi pada bilangan gelombang $3200-3400 \mathrm{~cm}^{-1}$, dan cincin benzen pada 1626, 1520, $1462 \mathrm{~cm}^{-1}$, sedangkan vibrasi ulur $\mathrm{C}-\mathrm{H}$ alifatik ditandai dengan munculnya puncak serapan didaerah 2923 dan $2852 \mathrm{~cm}^{-1}$.

\section{Kesimpulan}

Ekstrak daun teh efektif sebagai antibakteri terhadap bakteri $P$. fluorescens adalah isolat 2 . Isolat ini memiliki zona hambat sebesar $23,3 \mathrm{~mm}$. Ekstrak daun teh diduga mengandung senyawa EpiCatechin (EC).

\section{Daftar pustaka}

Amarowicz, R., Maryniak, A., \& Shahid, F. (2005). TLC separation of methylated (-)epigallocatechin-3-gallate. Czech J. Food Sci., 23(1), 36-39.

Ardiansyah. (2007, Juni 3). Antimikroba dari tumbuhan (bagian pertama). Retrieved 2009, from www.beritaiptek.com: http://www.beritaiptek.com/zberita-beritaiptek-2007-06-03-antimikroba-daritumbuhan-(bagian-pertama).shtml.htm

Buckle, K.A., Edwards, R.A., Fleet, G.H., \& Wotton, M. (2007). IImu pangan. Jakarta: UI Press.

Cheong, W.J., Park, M.H., Kang, G.W., Ko, J.H., \& Seo, Y.J. (2005). Determination of catechin compounds in korean green tea infusions under various extraction conditions by high performance liquid chromatography. Bull. Korean Chem. Soc., 26(5), 747-754.

Corpriady, J., Miharty, \& Herdini. (2001). Gallokatekin: senyawa flavonoid lainnya dari kulit batang tengas (Gluta renghas Linn.). Jurnal Natur Indonesia, 4(1).

Hadiwiyoto, S. (1993). Teknologi pengolahan hasil perikanan. Yogyakarta: Liberty.

Harbone, J. (1987). Metode fitokimia, penuntun cara modern menganalisis tumbuhan. Bandung: ITB Press.

Hartoyo, A. (2003). Teh dan khasiatnya bagi kesehatan. Yogyakarta: Kanisius. 
Hukmah, S. (2007). Aktivitas antioksidan katekin dari teh hijau (Camellia sinesis O.K. Var. Assamica (mast)) hasil ekstraksi dengan variasi pelarut dan suhu. Skripsi, Universitas Islam Negeri Maulana Malik Ibrahim, Kimia, Malang.

Robinson, T. (1995). Kandungan senyawa organik tumbuhan tinggi. (K. Padmawinata, Trans.) Bandung: ITB Press.

Sastrohamidjojo, H. (2005). Kromatografi. Yogyakarta: UGM Press.

Socrates, G. (1980). Infrared characteristic group frequencies. England.

Syah, A. N. (2006). Taklukkan penyakit dengan teh hijau. Jakarta: PT. Agromedia Pustaka. 